\title{
Potential Side-Effects of CSC Systemic Approach
}

\author{
Nelli Roosipuu ${ }^{1 *}$, Alina Vijulie ${ }^{2}$, Rosa Dolz-Marco ${ }^{3}$ and Roberto Gallego-Pinazo 4 \\ ${ }^{1}$ Unit of Macula, Department of Ophthalmology, University and Polytechnic Hospital La Fe, Valencia, Spain \\ ${ }^{2}$ Tartu University Eye Clinic, Estonia \\ ${ }^{3}$ Lucian Blaga University of Medicine, Sibiu, Romania
}

${ }^{4}$ Retics Oftared (RD12/0034), Prevention, Early Detection and Treatment of the Prevalent Degenerative and Chronic Ocular Pathology, Institute of Health Carlos III, Madrid, Spain

\section{Introduction}

Central serous chorioretinopathy (CSC) is characterized by the development of serous retinal detachment typically involving the macular area [1,2]. It may be recurrent in $30-50 \%$ of cases, leading to significant visual impairment [2]. Its etiopathogenesis remains uncertain, with a variety of genetic and environmental factors possibly involved [1,2]. Among these, the role of steroids has arisen as a potential therapeutic target with the use of mineralocorticoid inhibitors like spironolactone or eplerenone $[1,3]$.

The role of corticosteroids seems to be important in developing CSC. It has been found in CSC patients to have higher endogenous corticosteroid level or to have hypercortisolism due to a treatment of corticosteroids [2].

\section{Case Description}

Herein we report a case of a 49 -year-old man diagnosed with chronic CSC in his right eye three years earlier. His visual acuity was 20/30. The optical coherence tomography images evidenced a flat serous foveal detachment with outer nuclear layer atrophy. Given the chronicity and the persistence of subretinal fluid, treatment with laser photocoagulation, and intravitreal injections of ranibizumab and aflibercept had been performed with no significant benefit. After two years of follow-up the patient initiated treatment with oral spironolactone. In addition to the lack of efficacy of this approach, he developed mastodynia, nipple discharge and erectile dysfunction. A mammography failed to evidence any structural disturbance. Spironolactone was therefore discontinued and these symptoms resolved within 48 hours.

\section{Discussion}

Spironolactone is widely used in essential antihypertensive therapy, hyperaldosteronism, cirrhosis, congestive heart failure, nephrotic syndrome or hypokalemia. Gynecomastia is a frequent side-effect
(10\%) given its antiandrogenic effect, thus leading to increased free estradiol and total estradiol [3-6].

\section{Conclusion}

Ophthalmologists have traditionally been considered "earlyadopters" of new therapeutic agents or approached with lack of first level or scientific evidence. Actually spironolactone is widely used for chronic CSC although no large clinical trials has been conducted [7]. In our opinion, it is highly relevant to be familiar with the potential sideeffects of systemic therapies and to inform patients about these when prescribing off-label medications for ocular conditions.

\section{References}

1. Nicholson B, Noble J, Forooghian F, Meyerle C (2013) Central Serous Chorioretinopathy: Update on Pathophysiology and Treatment. Survey of Ophthalmology 58: 103-126.

2. Gemenetzi M, De Salvo G, Lotery AJ (2010) Central Serous Chorioretinopathy an update on pathogenesis and treatment. Eye (Lond) 24: 1743-1756.

3. Zhao $M$, Célérier I, Bousquet $E$, Jeanny J-C Jonet $L$ et al. (2012) Mineralocorticoid receptor is involved in rat and human ocular chorioretinopathy. $\mathrm{J}$ Clin Invest 122: 2672-2679.

4. González AG, Silvares EA, Mosquera MaD G, Vazquez AV (2005) Painful gynecomastia secondary to spironolactone. Semergen 31: 434-436.

5. Haynes BA, Mookadam F (2009) Male Gynecomastia. Mayo Clin Proc 84: 672

6. U.S. Food and Drug Administration.

7. Fine HF, Ober MD (2014) Current concepts in managing central serous choroidopathy. Ophthalmic Surg Lasers Imaging Retina 45: 9-13.

*Corresponding author: Nelli Roosipuu, Unit of Macula, Department of Ophthalmology, University and Polytechnic Hospital La Fe, Valencia, Spain, Tel: +372 56654324; E-mail: nelli.roosipuu@gmail.com

Received October 28, 2015; Accepted November 27, 2015; Published Novembe 30, 2015

Citation: Roosipuu N, VijulieA, Marco RD, Pinazo RG (2015) Potential Side-Effects of CSC Systemic Approach. J Steroids Horm Sci 6: 162. doi:10.4172/21577536.1000162

Copyright: (c) 2015 Roosipuu N, et al.. This is an open-access article distributed under the terms of the Creative Commons Attribution License, which permits unrestricted use, distribution, and reproduction in any medium, provided the original author and source are credited. 